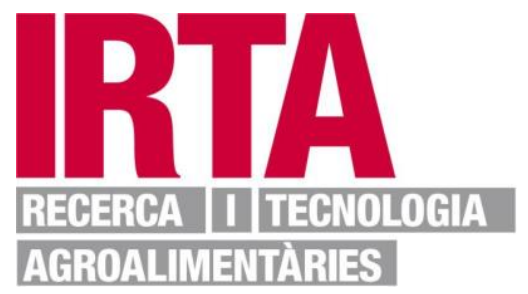

This is the peer reviewed version of the following article: Ribas-Agustí, Albert, Isabel Díaz, Carmen Sárraga, Jose A García-Regueiro, and Massimo Castellari. 2019. "Nutritional Properties Of Organic And Conventional Beef Meat At Retail".Journal Of The Science Of Food And Agriculture. Wiley. doi:10.1002/jsfa.9652., which has been published in final form at https://doi.org/10.1002/jsfa.9652. This article may be used for non-commercial purposes in accordance with Wiley Terms and Conditions for Use of Self-Archived Versions http://www.wileyauthors.com/self-archiving. 


\title{
Nutritional properties of organic and conventional beef meat at retail
}

\author{
A. Ribas-Agustí*, I. Díaz, C. Sárraga, J.A. García-Regueiro, M. Castellari
}

IRTA, Food Safety program, Finca Camps i Armet s/n, 17121 Monells, Spain.

\author{
*Corresponding author: \\ E-mail address: albert.ribas@irta.cat (A. Ribas-Agustí) \\ Telephone: +34972630052
}

Fax: +34972630980

This article has been accepted for publication and undergone full peer review but has not been through the copyediting, typesetting, pagination and proofreading process, which may lead to differences between this version and the Version of Record. Please cite this article as doi: 10.1002/jsfa.9652

This article is protected by copyright. All rights reserved. 


\begin{abstract}
BACKGROUND: Consumers perceive organic meat as having superior nutritional properties than conventional meat, although evidences from commercial samples are very scarce. This study compared the nutritional composition of organic and conventional beef meat sold at retail, including for the first time the bioactive compounds coenzyme $\mathrm{Q}_{10}$, carnosine, anserine, creatine, and taurine. Sampling comprised two muscles, Longissimus thoracis and Supraspinatus. RESULTS: Organic beef had $17 \%$ less cholesterol, $32 \%$ less fat, $16 \%$ less fatty acids, $24 \%$ less monounsaturated fatty acids, $170 \%$ more $\alpha$-linolenic acid, 24\% more $\alpha$-tocopherol, $53 \%$ more $\beta$-carotene, $34 \%$ more coenzyme $\mathrm{Q}_{10}$ and $72 \%$ more taurine than conventional beef. Differences between organic and conventional samples were clearly dependent on the muscle, as Longissimus thoracis and Supraspinatus showed different patterns of compounds accumulation. CONCLUSIONS: For the first time, to our knowledge, higher amount of bioactive compounds in organic beef meat is reported. Retail organic beef had higher nutritional value than retail conventional beef, resulting from betterbalanced lipid and bioactive compounds contents.
\end{abstract}

\title{
Keywords
}

Beef meat; Organic farming; Bioactive compounds; Lipid content; Coenzyme $\mathrm{Q}_{10}$; Taurine

This article is protected by copyright. All rights reserved. 


\section{Introduction}

Meat consumption is important in human diet to fully develop and maintain the optimal physiological and intellectual performances. In particular, beef meat is a rich source essential amino acids, vitamins, minerals and bioactive components. ${ }^{1}$ Concerning beef meat bioactive compounds, coenzyme $\mathrm{Q}_{10}$, carnosine, anserine, creatine and taurine have gained interest due to their recognized involvement in disease prevention. Dietary coenzyme $\mathrm{Q}_{10}$ has been related to antihypertensive effects and cardiac function improvement. ${ }^{2}$ Carnosine scavenges harmful products originated from oxidative stress and reduces the formation of advanced glycation end-products, which are involved in cardiovascular ischemic damage and Alzheimer's disease. ${ }^{3,4}$ Anserine, in combination with carnosine, has been suggested to improve physical capacity, cardiometabolic health and cognitive functioning in the elderly. ${ }^{5}$ Meat is one of the primary dietary sources of creatine, which has been suggested to have positive impact on the immune and neurological system. ${ }^{6}$ Creatine is also used by athletes as a dietary supplementation for improved muscle strength and performances. ${ }^{7}$ On the other hand, taurine has been shown to reduce the effects of obesity, by stimulating the energy expenditure and modulating the lipid metabolism. ${ }^{8}$ Taurine has also been suggested as a potential therapeutic agent in chronic inflammatory disorders. ${ }^{9}$

Despite the nutritional relevance of beef, some epidemiological studies support the classification of red meat as probably carcinogenic to humans, mainly due to the formation of harmful compounds during cooking, smoking or curing. ${ }^{10}$ Health concerns are also derived from the saturated fat content and cholesterol, although beef meat also contains beneficial omega-3 (n-3) polyunsaturated fatty acids (PUFA). Therefore, red meat has to be consumed in moderation in order to fit into a healthy diet. ${ }^{11}$ Anyhow, it is advisable that this moderate intake consists of minimally processed red meat with

This article is protected by copyright. All rights reserved. 
high nutritional quality, in order to provide healthy levels of proteins, essential amino acids, minerals, vitamins and bioactive components. ${ }^{12}$

Beef meat nutrients and bioactive contents largely depend on the muscle function and fiber type composition. For example, muscles with higher aerobic metabolism are found to contain more taurine and coenzyme $\mathrm{Q}_{10}$, and less carnosine and creatine. ${ }^{13}$ The production system also influences the nutritional value of beef meat. In this sense, the feed composition is a relevant factor affecting the nutritional profile, modulating the accumulation of fatty acids and other bioactive compounds. ${ }^{13,14} \alpha$ Tocopherol (vitamin E) and $\beta$-carotene (provitamin A) contents have been shown to be dependent on the feeding regime. ${ }^{15}$ Although meat is not an important dietary source of these two vitamins, their presence can be important in terms of meat stability due to their antioxidant activity. ${ }^{16}$

Organic farming has gained popularity among consumers, thanks to the use of sustainable feeding and breeding practices, and their higher standards of animal welfare. ${ }^{17}$ In addition, consumers perceive organic meat as having better quality and healthy attributes than conventionally produced livestock products, although few evidences exist. ${ }^{18,19}$ Namely, better balanced lipid profiles have been found in organic beef due to increased content in long chain $n-3$ fatty acids. ${ }^{20}$ Anyway, to the best of our knowledge, effects of organic farming on other beef meat bioactive components remain largely unknown.

Given the substantial lack of scientific data about the effects of organic farming on the nutritional value of beef meat, the objective of this study was to assess the nutritional parameters and bioactive compounds (water, collagen, protein, fat, fatty acids profile, cholesterol, $\alpha$-tocopherol, $\beta$-carotene, coenzyme $\mathrm{Q}_{10}$, anserine, carnosine, creatine and taurine) of commercially available organic and conventional beef meat, 
including two muscles with different fiber type composition and involvement in the physical activity: Longissimus thoracis (ribeye, LT) and Supraspinatus (mock tender, SS).

\section{Material and methods}

\section{Chemicals}

$\alpha$-Tocopherol, $\beta$-carotene, coenzyme $\mathrm{Q}_{10}$, creatine, carnosine, anserine, taurine, fatty acid methyl esters (FAME) mixture and formic acid were provided by SigmaAldrich (St. Louis, MO, USA). All solvents for compounds determinations were of chromatographic grade (Fisher Scientific, Madrid, Spain).

\section{Sampling and proximate composition}

Organic samples were obtained from seven Spanish major retail chains, including one LT and one SS sample from each store $(n=14)$. At the same time, conventional samples were obtained from the same retailers, including two LT and two SS samples from each store $(\mathrm{n}=28)$. Each sample had different origin and brand, and consisted of a tray-packaged piece of 200-1000 g. Sampling was concluded within a period of 3 months. The larger sampling size of conventional beef was aimed at being more representative of the higher number of available conventional items at retail. All organic samples were produced in Spain and were labelled with the EU organic logotype and the code of the control authorities. As the study was conducted on commercial samples from retail stores, varying farming practices, production, distribution and retailing conditions may have been involved. Samples were vacuumpacked in aluminum foil bags and stored at $-80{ }^{\circ} \mathrm{C}$ until analysis. Analytical determinations were performed in ground meat after removal of the subcutaneous and

This article is protected by copyright. All rights reserved. 
intermuscular fat and connective tissue. Protein, fat, collagen and water contents were determined in triplicate using a near infrared (NIR) meat analyzer (FoodScan, Foss, Hillerød, Denmark) with in-house calibrations. ${ }^{21}$

\section{Fatty acids determination}

Fatty acids were analyzed according to Mach et al. ${ }^{22}$ Briefly, $2 \mathrm{~g}$ of thawed sample were added with $2 \mathrm{mg}$ glyceryl tritridecanoate (internal standard) and homogenized with $100 \mathrm{~mL}$ of chloroform: methanol $(2: 1 \mathrm{v} / \mathrm{v})$ for $30 \mathrm{~min}$. The organic fraction was separated, and the extraction repeated twice by adding $0.1 \mathrm{~g} \mathrm{ml}^{-1}$ sodium chloride. Organic fractions were combined, and the solvent was evaporated with a rotary evaporator. FAME were obtained by following the ISO method $5509^{23}$ and analyzed using an HP 5890 Series II gas chromatograph (Hewlett Packard SA, Barcelona, Spain). Samples were introduced by split injection into a BPX70 fused silica capillary column $(30 \mathrm{~m} \times 0.25 \mathrm{~mm}$ i.d., $0.25 \mu \mathrm{m}$ film thickness - SGE, Milton Keynes, UK). Helium was the carrier gas at $30 \mathrm{~cm} \mathrm{~s}^{-1}$. The GC temperature was held at $150{ }^{\circ} \mathrm{C}$ for $1 \mathrm{~min}$, then increased at $4{ }^{\circ} \mathrm{C} \min ^{-1}$ to $200{ }^{\circ} \mathrm{C}$ and held for $10 \mathrm{~min}$. Individual fatty acids were identified by comparison of their retention times with those of pure standards. Quantification was made by using an internal standard calibration.

\section{Cholesterol determination}

Cholesterol was quantified following the procedure of Cayuela, Garrido, Bañón, \& Ross. ${ }^{24}$ Ground meat $(100 \mathrm{mg}$ ) was mixed with $1 \mathrm{mg}$ of $5 \alpha$-colestanol (internal standard) and treated with $7.3 \mathrm{~mL}$ of saponification solution $\left(115 \mathrm{~g} \mathrm{~kg}^{-1}\right.$ potassium hydroxide in $55 \%$ ethanol v/v) during $15 \mathrm{~min}$ at $80^{\circ} \mathrm{C}$. Then, cholesterol was extracted with $3 \mathrm{~mL}$ hexane and centrifuged (2,700 $\mathrm{g}, 10$ minutes). An aliquot from the upper 
organic phase was collected and evaporated to dryness with nitrogen. The residue was re-dissolved with mobile phase (acetonitrile: acetone, 50:50 v/v). Analysis was carried out using an HPLC (Waters, Milford, MA, USA), equipped with a refractive index (RI) detector (Waters). The separation was achieved using a Nucleosil 100-5 C18 column (4 $\times 250 \mathrm{~mm}$ i.d., $5 \mu \mathrm{m}$ particle size; Agilent) at a flow rate of $1.2 \mathrm{~mL} \mathrm{~min}{ }^{-1}$. Quantification was made using internal standard calibration.

\section{$\alpha$-Tocopherol, $\beta$-carotene and coenzyme $Q_{10}$ determination}

$\alpha$-Tocopherol, $\beta$-carotene and coenzyme $\mathrm{Q}_{10}$ were assessed by HPLC, with a protocol adapted from Purchas et al. ${ }^{25}$ and Karadas et al. ${ }^{26}$. All the procedure was conducted in subdued light. One gram of sample was mixed with $2 \mathrm{~mL} 0.15 \mathrm{M}$ sodium chloride. After homogenization and addition of $2 \mathrm{ml}$ of ethanol containing $0.1 \mathrm{~g} \mathrm{~kg}^{-1}$ BHT, samples were extracted with $5 \mathrm{ml}$ of hexane. Then, sample was gently stirred for $15 \mathrm{~min}$ and centrifuged at $4,000 \mathrm{~g}$ at $4{ }^{\circ} \mathrm{C}$ for $5 \mathrm{~min}$. The hexane layer was transferred into an amber bottle and the extraction was repeated two more times. Supernatants were collected and evaporated to dryness under nitrogen stream. The dried extract was reconstituted in $1 \mathrm{ml}$ of 2-propanol: acetonitrile $(2: 8, \mathrm{v} / \mathrm{v})$, filtered through $0.2 \mu \mathrm{m}$ PTFE filter and injected. Chromatographic separation was carried out in an Agilent 1100 system equipped with diode array (DAD) and fluorescence (FLD) detectors (Agilent Technologies, Palo Alto, CA, USA), and a Luna $5 \mu \mathrm{m}, \mathrm{C} 18(150 \mathrm{~mm} \times 4.6 \mathrm{~mm}$ i.d.) column (Phenomenex, Agilent, Torrance, CA, USA). Elution was performed at $1 \mathrm{ml}$ $\min ^{-1}$ with mobile phase varying linearly from $90 \%$ A (100\% acetonitrile) and $10 \% \mathrm{~B}$ (acetonitrile: tetrahydrofurane 20:80, v/v), to $100 \% \mathrm{~B}$ in 12 minutes. $\beta$-Carotene and coenzyme $\mathrm{Q}_{10}$ were detected by $\mathrm{DAD}$ at $445 \mathrm{~nm}$ and $275 \mathrm{~nm}$ (respectively), and $\alpha$ -

This article is protected by copyright. All rights reserved. 
tocopherol by FLD (Ex $280 \mathrm{~nm}$, Em $330 \mathrm{~nm}$ ). Quantification was made using calibration curves of the three standards $\left(0-50 \mu \mathrm{g} \mathrm{ml}^{-1}\right)$.

\section{Carnosine, anserine, creatine and taurine simultaneous determination}

Carnosine, anserine, creatine and taurine were extracted by adapting a method previously developed for porcine muscles. ${ }^{27}$ A portion of sample $(1 \mathrm{~g})$ was homogenized with $10 \mathrm{~mL}$ ultra-pure $0.01 \mathrm{~N}$ hydrochloric acid using an Ultra-Turrax disperser (IKA, Wilmington, NC, USA), and centrifuged at 4,500 $g$ for 5 min (Beckman Coulter, Brea, CA, USA). Two $\mathrm{mL}$ of the supernatant were added to $2 \mathrm{~mL}$ acetonitrile and stirred for one hour at $4{ }^{\circ} \mathrm{C}$. After centrifugation $\left(1,500 \mathrm{~g}, 3 \mathrm{~min}, 4{ }^{\circ} \mathrm{C}\right), 1 \mathrm{~mL}$ of the supernatant was diluted up to $25 \mathrm{~mL}$ with $0.1 \%$ (v/v) formic acid.

One ml was added with $25 \mu \mathrm{l}$ of creatinine- $\mathrm{d}_{3}$ (internal standard) solution at 50 $\mu \mathrm{g} \mathrm{mL} \mathrm{m}^{-1}$, filtered through PTFE and injected $(5 \mu \mathrm{L})$ in an Acquity UHPLC system, equipped with a triple quadrupole mass detector (Waters). The chromatographic separation was carried out with an HSS T3 column $(150 \mathrm{~mm} \times 1.0 \mathrm{~mm}$ i.d., $1.8 \mu \mathrm{m}$ particle size, Waters) with isocratic elution of mobile phase A (water: formic acid: acetonitrile, 979:1:20 v/v/v) at a flow rate of $0.130 \mathrm{~mL} \min ^{-1}$, followed by a washing step with mobile phase B (water: formic acid: acetonitrile, 299:1:700 v/v/v) during 1 min. The electrospray ionization (ESI) source operated in the positive mode with a capillary voltage set at $+3 \mathrm{KV}$. The source temperature was held at $140{ }^{\circ} \mathrm{C}$ and the

desolvation temperature at $350{ }^{\circ} \mathrm{C}$. Desolvation gas (nitrogen) flow rate was $350 \mathrm{~L} \mathrm{~h}^{-1}$, the cone gas (nitrogen) flow rate was $25 \mathrm{~L} \mathrm{~h}^{-1}$ and the collision gas (argon) flow rate was $0.10 \mathrm{~mL} \mathrm{~min}^{-1}$.

Target compounds were quantified by Multiple Reaction Monitoring (MRM) operating at unit resolution. MRM conditions were optimized with the Autotune Wizard

This article is protected by copyright. All rights reserved. 
tool (MassLynx software, Waters) by infusing standard solutions $\left(10 \mathrm{mg} \mathrm{L}^{-1}\right)$ of each compound separately. Calibration curves were created by analyzing a sample of pooled meat spiked with known amounts of standards, using the peak area ratio of each compound to the internal standard in the MRM mode. Limits of detection (LOD) were calculated based on the calibration curves, as the concentration corresponding to a signal to noise ratio $(s / n)$ of 3 . Absolute recoveries were estimated by comparing the response of three control samples, spiked before extraction with known amounts of pure standards, with the response of the same samples spiked after extraction at the same concentrations. Repeatability of the method was estimated by analyzing three samples per triplicate the same day (intraday) and three different days (interday).

\section{Statistical analysis}

Data were analyzed with a full factorial 2-way ANOVA (JMP 8.0.1, SAS Institute, Cary, NC, USA), considering production system and muscle as factors, and their interaction. Mean differences were tested by the LS Means Student's $\mathrm{t}(p<0.05)$.

\section{Results and discussion}

\section{Simultaneous analysis of anserine, carnosine, creatine and taurine.}

A new UHPLC-MS method was developed for the simultaneous evaluation of anserine, carnosine, creatine and taurine. The main validation parameters of the method are presented in Table 1 . The target compounds were identified by comparing retention time and two specific MRM transitions of the deprotonated molecular ions with the corresponding data obtained from pure standard solutions. Recovery varied from $98.3 \%$ to $102.3 \%$, LOD from 2.8 to $94 \mu \mathrm{g} \mathrm{g}^{-1}$, and repeatability had RSD values always below 
$6.0 \%$. These results confirmed the method suitability for the quantification of the four bioactive compounds in meat samples.

The simultaneous determination of meat bioactive compounds has been described previously by few works. Zinellu et al. ${ }^{28}$ developed a method for the determination of carnosine, homocarnosine and anserine by capillary electrophoresis and UV detection. Some chromatographic methods have been described as well. A work by Aristoy et al. ${ }^{27}$ showed a reverse-phase HPLC method for the evaluation of carnosine, anserine and taurine, after derivatization to their phenylthiocarbamyl derivatives. Purchas et al. ${ }^{25}$ determined taurine and carnosine by cation exchange chromatography, and another work, described a hydrophilic interaction chromatography (HILIC) procedure for the simultaneous determination of carnosine, anserine, balenine, creatine and creatinine in meat. ${ }^{29}$ The present work presents a new reverse phase HPLCDAD-MS methodology, not requiring sample cleanup or derivatization, for the simultaneous determination of anserine, carnosine, creatine and taurine in meat.

\section{Effects of muscle}

The two muscles included in this study showed significant differences in their nutritional composition and bioactive contents (Table 2). LT samples had higher contents in protein, fat, saturated fatty acids (myristic acid, palmitic acid and stearic acid), elaidic acid (monounsaturated fatty acid, MUFA), carnosine and anserine. On the other hand, SS muscle contained higher water, collagen, polyunsaturated fatty acids (PUFA, eicosatrienoic acid and arachidonic acid), $\alpha$-tocopherol, coenzyme $\mathrm{Q}_{10}$ and taurine contents.

Differences in bioactive composition according to the muscle type are well documented. ${ }^{30,31}$ These differences can be attributed to the energy requirements and the 
metabolic differentiation between muscle types, as a consequence of their different involvement in the animal physical activity. In this sense, LT extends the vertebral column and participates in flexion and extension movements that require lower energy demand than SS, which is used in locomotion. Cattle SS contains higher percentage of fibers having high oxidative enzyme activity than LT, which is more adapted to contraction by anaerobic glycogenolysis (fast-twitch-glycolytic fibers). ${ }^{32}$ The results are in agreement with previous reports describing higher taurine and coenzyme $\mathrm{Q}_{10}$ contents and lower carnosine and anserine contents in muscles requiring higher percentage of aerobic metabolism. ${ }^{13,27}$

\section{Collagen, protein and water contents in organic and conventional beef}

Organic beef contained more collagen and water than conventional beef, while their protein contents were similar (Table 2). In the case of moisture, differences were found according to the muscle, as shown by the significant interaction between production system and muscle factors (Table 2). In this regard, the higher water content in organic samples was due to the LT muscle, as SS water was similar in both organic and conventional beef (Figure 1).

The absence of protein differences between organic and conventional beef is in agreement with the results of a comprehensive meta-analysis for protein contents in organic and conventional meat. ${ }^{19}$ Conversely, the same meta-analysis did not find significant differences in water content. To our knowledge, this is the first work showing collagen differences between organic and conventional beef meat. Different factors, such as animal activity and diet, might have influenced the significant effects found in the present study.

\section{Lipid contents in organic and conventional beef}

This article is protected by copyright. All rights reserved. 
Organic beef meat had $17 \%$ less cholesterol, $32 \%$ less fat, $16 \%$ less total fatty acids, $17 \%$ less palmitic acid (saturated fatty acid) and 24\% less MUFA (including palmitoleic acid, elaidic acid, oleic acid and vaccenic acid) than conventionally produced beef meat (Table 2). Concerning total PUFA, no significant differences were observed, although organic beef contained $170 \%$ more $\alpha$-linolenic acid ( $n-3), 46 \%$ less eicosatrienoic acid (n-6) and 40\% less arachidonic acid (n-6) than conventional beef.

In many instances, the differences in lipid profile between organic and conventional beef depended on the muscle, as shown by the significant interactions between production system and muscle factors (Table 2). Among lipids influenced by the production system, there was no interaction for palmitic acid, oleic acid, total fatty acids and cholesterol, hence the effects of organic farming on these compounds were similar in SS and LT muscles. The rest of lipids could be listed in four categories according to their muscle-dependent response $(P<0.05)$ under organic farming $($ Fig. 1$)$ :

i) Higher content in LT: Linoleic acid and $\alpha$-linolenic acid.

ii) Higher content in SS: $\alpha$-Linolenic acid (higher effect than LT).

iii) Lower content in LT: Fat, myristic acid, margaric acid, palmitoleic acid, elaidic acid and vaccenic acid.

iv) Lower content in SS: Eicosatrienoic acid, arachidonic acid and total PUFA.

Previous works comparing organic and conventional lipid profiles in cattle meat have shown contrasting results. Lower fat, cholesterol and MUFA, and higher saturated fatty acids, PUFA and $n$-3 PUFA contents have been reported in LT samples of organic beef. ${ }^{33}$ Other reports showed higher concentrations of vaccenic acid (MUFA) and $n-3$ PUFA in organic beef meat. ${ }^{20,34}$ Higher fat content and no significant differences in fatty acids profile has also been reported in organic compared to conventional steer meat. ${ }^{35}$ A meta-analysis on livestock meat showed similar or slightly lower saturated 
and MUFA concentration under organic production, while larger increased contents were found for PUFA and $n-3$ PUFA. ${ }^{19}$

It has been stated that the feeding regime is a main factor affecting meat fatty acid composition. ${ }^{36}$ The European Regulation 834/2007 on organic production stipulates that organic livestock shall have permanent access to open air areas, preferably pasture. ${ }^{37}$ In line with this, results showed that organic samples contained lower MUFA and higher $n$-3 PUFA contents, which is indicative of a grass-based diet. $^{36,38}$ On the other hand, it has been shown that lipid concentrations in beef meat are highly dependent on the muscle. ${ }^{30,31}$ In this work, muscles appeared to have different tendency to accumulate certain lipids under conventional or organic production systems. The muscle function could have determined the fat accumulation in beef bred under conventional farming, as it took place principally in the muscle less involved in locomotion (LT).

A number of epidemiological studies have correlated fat and cholesterol intake with cardiovascular disease and cancer. ${ }^{39}, 40$ The results showed that cholesterol and overall fatty acids contents in retail organic beef were better-balanced than in retail conventional beef.

\section{$\alpha$-Tocopherol and $\beta$-carotene contents in organic and conventional beef}

Organic beef contained 24\% more $\alpha$-tocopherol (vitamin E) and 53\% more $\beta$ carotene (provitamin A) than conventional beef (Table 2). More precisely, differences were found in LT muscles, as organic LT contained 50\% more $\alpha$-tocopherol and $341 \%$ more $\beta$-carotene than conventional LT, whereas no significant differences were found in the SS muscle (Figure 1).

This article is protected by copyright. All rights reserved. 
The effect of organic farming on $\alpha$-tocopherol and $\beta$-carotene contents can be attributed to the type of feed made available to the animals, given that a portion of the dietary intake accumulates into the body fat. Unlike conventional systems, certified organic beef must have access to pasture, so at least some of their diet comes from grass. ${ }^{37}$ In agreement, it has been found that meat from beef fed with grass-rich diets contained higher $\beta$-carotene, their retinoid derivatives and $\alpha$-tocopherol contents. ${ }^{36,41}$

In the case of conventional LT and SS, results showed that fat content and fatsoluble $\alpha$-tocopherol and $\beta$-carotene contents had an opposite relationship, which was not found in organic LT and SS muscles (Figure 1). Hence, it is most likely that this effect was triggered by some specific breeding practices affecting conventional beef, such as type of feed or low physical activity. Under these conditions, the occurrence of a differentiated accumulation pattern of fat and fat-soluble vitamins in both muscles might be due to differences in their metabolism. Other works have also reported this opposite trend in bovine muscles. ${ }^{30,42}$

Beef meat is not an important dietary source of $\alpha$-tocopherol and $\beta$-carotene, however, their presence in meat is important in terms of shelf life, thanks to their antioxidant and radical scavenging activity. It has been reported that endogenous $\alpha$ tocopherol increases meat color stability and delays lipid oxidation. ${ }^{16}$ Similarly, $\beta$ carotene contributes to the meat preservation against oxidation, by quenching reactive oxygen species and retarding lipid and protein oxidation. ${ }^{43}$ It has been shown that $\beta$ carotene acts synergistically with $\alpha$-tocopherol on avoiding lipid peroxidation. ${ }^{44}$ The higher antioxidant contents can be particularly beneficial for extending shelf life of organic beef due to its higher concentration of easily oxidizable $n-3$ PUFA. ${ }^{36}$

\section{Bioactive compounds contents in organic and conventional beef}

This article is protected by copyright. All rights reserved. 
Coenzyme $\mathrm{Q}_{10}$ participates in the electron transport chain in mitochondria, for which is required during aerobic cellular respiration. Carnosine and anserine are cytosolic antioxidants, which are believed to reduce muscle fatigue and prevent cell damage from harmful products of oxidative stress. Creatine is involved in the recycling of adenosine triphosphate (ATP) through the phosphocreatine system. After its synthesis in liver and kidneys, it is transported to tissues with high-energy demand, mainly skeletal muscle and brain, where high use of ATP is required. Taurine is essential for normal skeletal muscle functioning, as it is involved in muscle contraction, regulation and defense from oxidative stress. ${ }^{45}$ As all of these compounds are directly involved in muscle metabolism, their synthesis and levels in meat may depend on the animal physical activity and dietary factors. To the best of our knowledge, this is the first work assessing coenzyme $\mathrm{Q}_{10}$, carnosine, anserine, creatine, and taurine contents in organic and conventional beef meat at retail.

Organic beef contained $72 \%$ and $34 \%$ higher taurine and coenzyme $\mathrm{Q}_{10}$ contents (respectively), while no differences were found for anserine, carnosine and creatine (Table 2). The increase in coenzyme $\mathrm{Q}_{10}$ contents in organic with respect to conventional beef was found to be similar in both LT and SS muscles. However, production system had significant interaction with muscle type for carnosine, anserine and taurine. Thus, carnosine and anserine contents were higher in organic LT, and taurine in organic SS (Figure 1).

Martino et al. $^{46}$ reported increased coenzyme $\mathrm{Q}_{10}$ and decreased anserine and carnosine levels in organic pig meat with respect to the conventional counterpart. According to the literature on cattle meat, the contents in taurine and coenzyme $\mathrm{Q}_{10}$ could have been influenced by the feeding practice. In this sense, higher concentrations of taurine, carnosine and coenzyme $\mathrm{Q}_{10}$ have been found in meat from cattle finished on 
pasture. ${ }^{13}$ Also, higher levels of taurine have been reported in steers grazed and finished on wheat instead of rye. ${ }^{47}$

With regard to the differences between organic and conventional beef depending on the muscle, previous works have related high carnosine and anserine levels to anaerobic metabolism (glycolysis), and taurine to oxidative metabolism. ${ }^{27,30}$ Therefore, the increase in carnosine and anserine in LT (glycolytic enzyme activity) and taurine in SS (oxidative enzyme activity) could be a sign of enhanced energy expenditure. It is noteworthy to mention that other factors, such as animals' age, breed or metabolic status, could have also influenced the taurine, coenzyme $\mathrm{Q}_{10}$, carnosine and anserine higher contents in organic samples. ${ }^{48}$

Several health benefits have been attributed to the intake of coenzyme $\mathrm{Q}_{10}$, anserine, carnosine and taurine. Several studies have correlated deficiency of coenzyme $\mathrm{Q}_{10}$ with cardiovascular disease, cancer and neurodegenerative diseases. Carnosine and anserine scavenge harmful products originated from oxidative stress, and have been related to protective effects against cardiovascular and neurodegenerative diseases. ${ }^{3-5}$ On the other hand, taurine possess anti-inflammatory and anti-oxidative effects. It has been related to lower risk of obesity through the stimulation of energy expenditure. ${ }^{8}$

\section{Conclusions}

This is the first time, to our knowledge, that an exhaustive evaluation of the beef meat nutritional value, including coenzyme $\mathrm{Q}_{10}$, carnosine, anserine, creatine and taurine, is reported for organic samples. The results showed that organic beef, from Spanish retail outlets, had higher nutritional value than beef produced under conventional farming. This statement is based on reduced cholesterol and fat, and higher contents in $\alpha$-linolenic acid, $\alpha$-tocopherol, $\beta$-carotene, coenzyme $\mathrm{Q}_{10}$, taurine, anserine 
and carnosine, depending on the muscle. The difference in nutritional value was probably triggered by multiple factors, such as the feeding regime (e.g. pasture) or animals' breed, age, physical activity and welfare, although further studies with controlled husbandry factors would be required in order to determine their specific effects. Results clearly depended on the muscle, as LT and SS showed divergences on the accumulation of compounds driven by the production system. The causes of these muscle divergences might be related to their different function in the animal activity and metabolic requirements. Since meat intake should be limited in a healthy diet, organic beef is a recommendable choice due to its better-balanced lipid profile and bioactive content beside conventionally raised beef.

\section{Acknowledgements:}

This work was supported by the Spanish Ministry of Education and Science (Consolider-Ingenio 2010 CSD2007-00016); and CERCA Programme (Generalitat de Catalunya).

This article is protected by copyright. All rights reserved. 


\section{References}

1. Pereira PM and Vicente AF. Meat nutritional composition and nutritive role in the human diet. Meat Sci 93:586-592 (2013).

2. Kumar A, Kaur H, Devi P and Mohan V. Role of coenzyme Q10 (CoQ10) in cardiac disease, hypertension and Meniere-like syndrome. Pharmacol Therapeut 124:259-268 (2009).

3. Bellia F, Vecchio $G$ and Rizzarelli E. Carnosine and cognitive deficits. In: Martin CR and Preedy V. (eds). Diet and Nutrition in Dementia and Cognitive Decline. San Diego: Academic Press, 2015; 973-982.

4. Guiotto A, Calderan A, Ruzza P and Borin G. Carnosine and carnosine-related antioxidants: a review. Curr Med Chem 12:2293-2315 (2005).

5. Szcześniak D, Budzeń S, Kopeć W and Rymaszewska J. Anserine and carnosine supplementation in the elderly: Effects on cognitive functioning and physical capacity. Arch Gerontol Geriatr 59:485-490 (2014).

6. Riesberg LA, Weed SA, McDonald TL, Eckerson JM and Drescher KM. Beyond muscles: The untapped potential of creatine. Int Immunopharmacol 37:31-42 (2016).

7. Eckerson JM. Creatine as an ergogenic aid for female athletes. Strength Cond J 38:14-23 (2016).

8. Murakami S. The physiological and pathophysiological roles of taurine in adipose tissue in relation to obesity. Life Sci 186:80-86 (2017).

9. Nam SY, Kim HM and Jeong HJ. The potential protective role of taurine against experimental allergic inflammation. Life Sci 184:18-24 (2017).

This article is protected by copyright. All rights reserved. 
10. IARC. IARC monographs on the evaluation of carcinogenic risk to humans. Volume 114 - Red meat and processed meat. Lyon: International Agency for Research on Cancer, 2018.

11. Wyness L. The role of red meat in the diet: nutrition and health benefits. Proc Nutr Soc 75:227-232 (2016).

12. Binnie MA, Barlow K, Johnson V and Harrison C. Red meats: Time for a paradigm shift in dietary advice. Meat Sci 98:445-451 (2014).

13. Purchas RW and Busboom JR. The effect of production system and age on levels of iron, taurine, carnosine, coenzyme Q(10), and creatine in beef muscles and liver. Meat Sci 70:589-596 (2005).

14. Razminowicz RH, Kreuzer M and Scheeder MR. Quality of retail beef from two grass-based production systems in comparison with conventional beef. Meat Sci 73:351$361(2006)$

15. Yang A, Brewster MJ, Lanari MC and Tume RK. Effect of vitamin E supplementation on $\alpha$-tocopherol and $\beta$-carotene concentrations in tissues from pastureand grain-fed cattle. Meat Sci 60:35-40 (2002).

16. Liu Q, Lanari $\mathrm{MC}$ and Schaefer DM. A review of dietary vitamin $\mathrm{E}$ supplementation for improvement of beef quality. J Anim Sci 73:3131-3140 (1995).

17. Sundrum A. Organic livestock farming: A critical review. Livest Prod Sci 67:207-215 (2001).

18. Shan LC, De Brun A, Henchion M, Li C, Murrin C, Wall PG and Monahan FJ. Consumer evaluations of processed meat products reformulated to be healthier - A conjoint analysis study. Meat Sci 131:82-89 (2017).

19. Średnicka-Tober D, Barański M, Seal C, Sanderson R, Benbrook C, Steinshamn H, Gromadzka-Ostrowska J, Rembiałkowska E, Skwarło-Sońta K, Eyre M, Cozzi G, 
Larsen MK, Jordon T, Niggli U, Sakowski T, Calder PC, Burdge GC, Sotiraki S, Stefanakis A, Yolcu H, Stergiadis S, Chatzidimitriou E, Butler G, Stewart G and Leifert C. Composition differences between organic and conventional meat: a systematic literature review and meta-analysis. Br J Nutr 115:994-1011 (2016).

20. Kamihiro S, Stergiadis S, Leifert C, Eyre MD and Butler G. Meat quality and health implications of organic and conventional beef production. Meat Sci 100:306-318 (2015).

21. Anderson S. Determination of fat, moisture, and protein in meat and meat products by using the FOSS FoodScan Near-Infrared Spectrophotometer with FOSS Artificial Neural Network Calibration Model and Associated Database: collaborative study. J AOAC Int 90:1073-1083 (2007).

22. Mach N, Devant M, Díaz I, Font-Furnols M, Oliver MA, García-Regueiro JA and Bach A. Increasing the amount of n-3 fatty acid in meat from young Holstein bulls through nutrition. J Anim Sci 84:3039-3048 (2006).

23. International Organization for Standardization. ISO 5509:1978. Animal and vegetable fats and oils - Preparation of methyl esters of fatty acids. Geneve: International Organization for Standardization, 1978.

24. Cayuela JM, Garrido MD, Bañón SJ and Ros JM. Simultaneous HPLC analysis of $\alpha$-tocopherol and cholesterol in fresh pig meat. J Agric Food Chem 51:1120-1124 (2003).

25. Purchas RW, Rutherfurd SM, Pearce PD, Vather R and Wilkinson BH. Concentrations in beef and lamb of taurine, carnosine, coenzyme $Q(10)$, and creatine. Meat Sci 66:629-637 (2004).

26. Karadas F, Surai PF, Sparks NH and Grammenidis E. Effects of maternal dietary supplementation with three sources of carotenoids on the retinyl esters of egg yolk and

This article is protected by copyright. All rights reserved. 
developing quail liver. Comp Biochem Physiol A Mol Integr Physiol 140:430-435 (2005).

27. Aristoy MC and Toldrá F. Concentration of free amino acids and dipeptides in porcine skeletal muscles with different oxidative patterns. Meat Sci 50:327-332 (1998).

28. Zinellu A, Sotgia S, Campesi I, Franconi F, Deiana L and Carru C. Measurement of carnosine, homocarnosine and anserine by FASI capillary electrophoresis UV detection: Applications on biological samples. Talanta 84:931-935 (2011).

29. Mora L, Sentandreu MA and Toldrá F. Hydrophilic chromatographic determination of carnosine, anserine, balenine, creatine, and creatinine. J Agric Food Chem 55:4664-4669 (2007).

30. Purchas RW and Zou M. Composition and quality differences between the longissimus and infraspinatus muscles for several groups of pasture-finished cattle. Meat Sci 80:470-479 (2008).

31. Sexten AK, Krehbiel CR, Dillwith JW, Madden RD, McMurphy CP, Lalman DL and Mateescu RG. Effect of muscle type, sire breed, and time of weaning on fatty acid composition of finishing steers. J Anim Sci 90:616-625 (2012).

32. Suzuki A and Tamate H. Histochemical classification of skeletal muscle fibers in the cattle. Acta Histochem Cytochem 7:319-327 (1974).

33. Miotello S, Bondesan V, Tagliapietra F, Schiavon S and Bailoni L. Meat quality of calves obtained from organic and conventional farming. Ital J Anim Sci 8:213-215 (2009).

34. Pestana JM, Costa AS, Martins SV, Alfaia CM, Alves SP, Lopes PA, Bessa RJ and Prates JA. Effect of slaughter season and muscle type on the fatty acid composition, including conjugated linoleic acid isomers, and nutritional value of intramuscular fat in organic beef. J Sci Food Agric 92:2428-2435 (2012).

This article is protected by copyright. All rights reserved. 
35. Walshe BE, Sheehan EM, Delahunty CM, Morrissey PA and Kerry JP. Composition, sensory and shelf life stability analyses of Longissimus dorsi muscle from steers reared under organic and conventional production systems. Meat Sci 73:319-325 (2006).

36. Daley CA, Abbott A, Doyle PS, Nader GA and Larson S. A review of fatty acid profiles and antioxidant content in grass-fed and grain-fed beef. Nutr J 9:10 (2010).

37. The Council of the European Union. Council Regulation (EC) No 834/2007 of 28 June 2007 on organic production and labelling of organic products and repealing Regulation (EEC) No 2092/91. Official Journal of the European Union, 20.7.2007, L189 (2007).

38. Freitas AK, Lobato JF, Cardoso LL, Tarouco JU, Vieira RM, Dillenburg DR and Castro I. Nutritional composition of the meat of Hereford and Braford steers finished on pastures or in a feedlot in southern Brazil. Meat Sci 96:353-360 (2014).

39. LaRosa JC, Hunninghake D, Bush D, Criqui MH, Getz GS, Gotto AM, Jr., Grundy SM, Rakita L, Robertson RM, Weisfeldt ML et al. The cholesterol facts. A summary of the evidence relating dietary fats, serum cholesterol, and coronary heart disease. A joint statement by the American Heart Association and the National Heart, Lung, and Blood Institute. The Task Force on Cholesterol Issues, American Heart Association. Circulation 81:1721-1733 (1990).

40. Rose DP, Boyar AP and Wynder EL. International comparisons of mortality rates for cancer of the breast, ovary, prostate, and colon, and per capita food consumption. Cancer 58:2363-2371 (1986).

41. Darwish WS, Ikenaka Y, Morshdy AE, Eldesoky KI, Nakayama S, Mizukawa H and Ishizuka M. $\beta$-Carotene and retinol contents in the meat of herbivorous ungulates

This article is protected by copyright. All rights reserved. 
with a special reference to their public health importance. J Vet Med Sci 78:351-354 (2016).

42. Roseiro LC, Santos C, Gonçalves H, Moniz C, Afonso I, Tavares M and da Ponte DJ. Concentration of antioxidants in two muscles of mature dairy cows from Azores. Meat Sci 96:870-875 (2014).

43. Descalzo AM and Sancho AM. A review of natural antioxidants and their effects on oxidative status, odor and quality of fresh beef produced in Argentina. Meat Sci 79:423-436 (2008).

44. Toyosaki T. Antioxidant effect of beta-carotene on lipid peroxidation and synergism with tocopherol in an emulsified linoleic acid model system. Int J Food Sci Nutr 53:419-423 (2002).

45. Prosser CL (ed). Comparative Animal Physiology, Environmental and Metabolic Animal Physiology. Hoboken, NJ: John Wiley \& Sons (1991).

46. Martino G, Mugnai C, Compagnone D, Grotta L, Del Carlo M and Sarti F. Comparison of performance, meat lipids and oxidative status of pigs from commercial breed and organic crossbreed. Animals 4:348-360 (2014).

47. Phillips HN, Heins BJ, Delate K and Turnbull R. Impact of grazing dairy steers on winter rye (Secale cereale) versus winter wheat (Triticum aestivum) and effects on meat quality, fatty acid and amino acid profiles, and consumer acceptability of organic beef. Plos One 12:e187686 (2017).

48. Watanabe A, Ueda Y and Higuchi M. Effects of slaughter age on the levels of free amino acids and dipeptides in fattening cattle. Anim Sci J 75:361-367 (2004).

This article is protected by copyright. All rights reserved. 


\section{Figure legends}

Figure 1. Interaction effects between production system and muscle on the nutritional and bioactive contents in commercially available beef meat. Asterisks indicate significant differences between conventional and organic production within muscles $(*$ $\mathrm{P}<0.05 ; * * \mathrm{P}<0.01 ; * * * \mathrm{P}<0.001)$. LT: Longissimus thoracis; SS: Supraspinatus; AA: arachidonic acid; ALA: $\alpha$-linolenic acid; EA: eicosatrienoic acid; PA: palmitoleic acid; PUFA: polyunsaturated fatty acids.
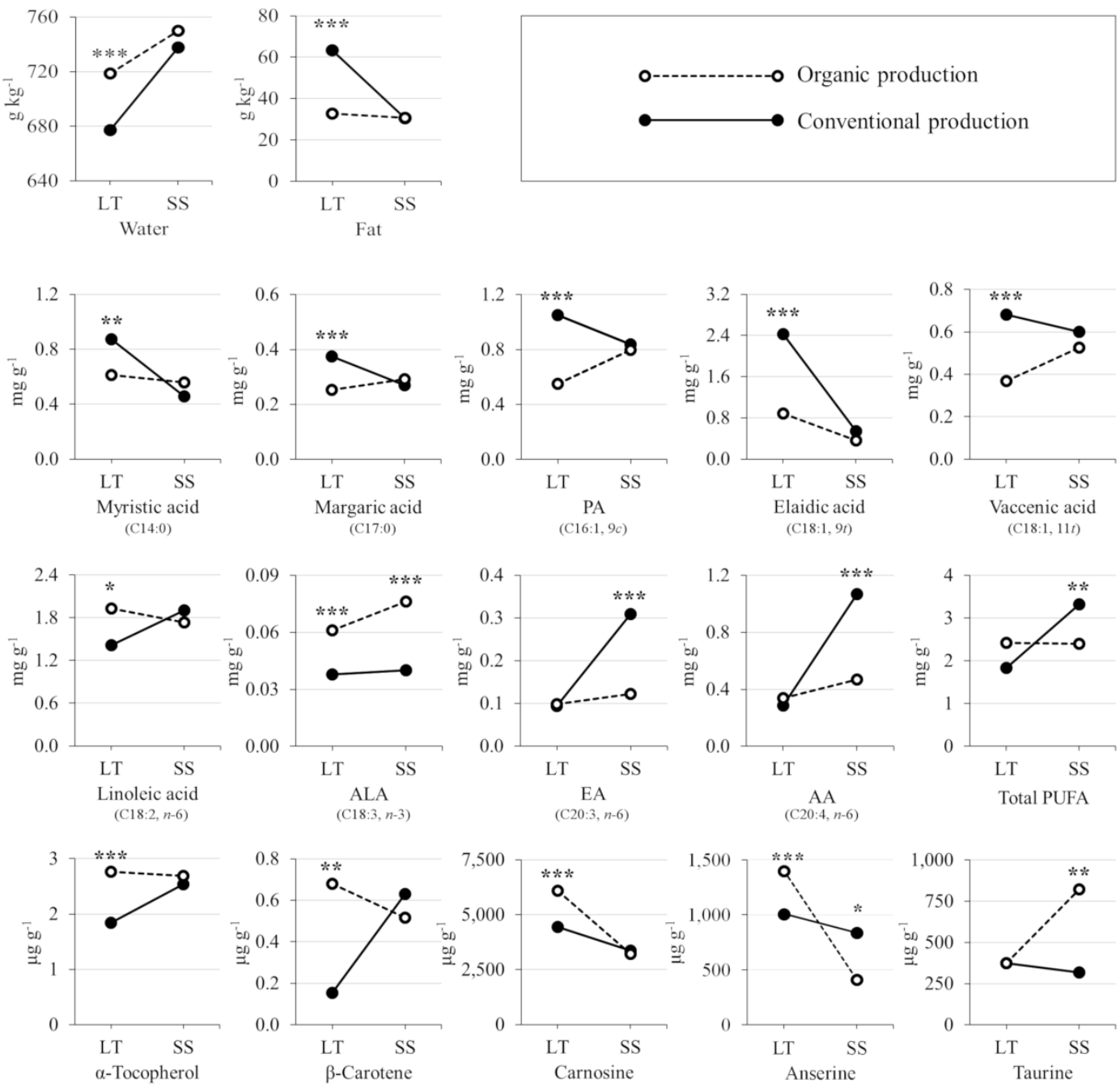

This article is protected by copyright. All rights reserved. 
Table 1. Performance and validation parameters of the UHPLC-MS method for the simultaneous analysis of anserine, carnosine, creatine and taurine

\begin{tabular}{|c|c|c|c|c|c|c|c|c|c|c|c|c|c|}
\hline & Rete & & Co & $\begin{array}{l}\text { Coll } \\
\text { isio }\end{array}$ & & & Calib & ratic & on curve ${ }^{\dagger}$ & $\begin{array}{l}\mathrm{L} \\
\mathrm{O}\end{array}$ & & $\begin{array}{l}\text { Repe } \\
\text { ty }(\%\end{array}$ & $\begin{array}{l}\text { tabili } \\
\text { RSD) }\end{array}$ \\
\hline & $\begin{array}{c}\mathrm{n} \\
\text { time } \\
(\mathrm{mi} \\
\mathrm{n})\end{array}$ & $\begin{array}{c}+\mathrm{H} \\
]^{+} \\
(m / \\
z)\end{array}$ & $\begin{array}{c}\text { vol } \\
\text { tag } \\
\mathrm{e} \\
\text { (V) }\end{array}$ & $\begin{array}{c}\text { ener } \\
\text { gy } \\
(\mathrm{eV} \\
)\end{array}$ & $\begin{array}{c}\text { MRM } \\
\text { transit } \\
\text { ions } \\
(\mathrm{m} / \mathrm{z})\end{array}$ & $\mathrm{a}$ & b & $\mathrm{R}^{2}$ & $\begin{array}{l}\text { Linearity } \\
\text { range }(\mu \mathrm{g} \\
\left.\mathrm{g}^{-1}\right)\end{array}$ & $\begin{array}{l}(\mu \\
\mathrm{g} \\
\mathrm{g}^{-} \\
1)\end{array}$ & $\begin{array}{c}\text { Rec } \\
\text { over } \\
\mathrm{y} \\
(\%)\end{array}$ & $\begin{array}{c}\text { Intra } \\
\text { day }\end{array}$ & $\begin{array}{c}\text { Inter } \\
\text { day }\end{array}$ \\
\hline $\begin{array}{l}\text { Ans } \\
\text { erin } \\
\mathrm{e}\end{array}$ & 0.80 & $\begin{array}{c}241 \\
.2\end{array}$ & 36 & 16 & $\begin{array}{c}241.2 \\
> \\
109.1 \\
241.2 \\
> \\
170.1\end{array}$ & $\begin{array}{c}0 . \\
84 \\
8\end{array}$ & $\begin{array}{c}0 . \\
00 \\
4\end{array}$ & $\begin{array}{c}0 . \\
99 \\
8\end{array}$ & $5000-50$ & $\begin{array}{l}9 \\
4 . \\
0\end{array}$ & 99.4 & 3.7 & 5.6 \\
\hline $\begin{array}{l}\text { Car } \\
\text { nosi } \\
\text { ne }\end{array}$ & 0.79 & $\begin{array}{c}227 \\
.2\end{array}$ & 26 & 14 & $\begin{array}{c}227.2 \\
> \\
110.1 \\
227.2 \\
> \\
156.1\end{array}$ & $\begin{array}{l}15 \\
.6 \\
8\end{array}$ & $\begin{array}{c}0 . \\
10 \\
1\end{array}$ & $\begin{array}{c}0 . \\
99 \\
9\end{array}$ & $10000-500$ & $\begin{array}{l}1 \\
5 . \\
0\end{array}$ & 98.5 & 4.0 & 4.8 \\
\hline $\begin{array}{l}\text { Crea } \\
\text { tine }\end{array}$ & 0.92 & $\begin{array}{c}132 \\
.1\end{array}$ & 28 & $\begin{array}{l}14 \\
10\end{array}$ & $\begin{array}{c}132.1 \\
>44.2 \\
132.1 \\
>44.2\end{array}$ & $\begin{array}{c}15 \\
.0 \\
8\end{array}$ & $\begin{array}{c}0 . \\
10 \\
7\end{array}$ & $\begin{array}{c}0 . \\
99 \\
9\end{array}$ & $2000-100$ & $\begin{array}{l}2 . \\
8\end{array}$ & $\begin{array}{c}102 . \\
3\end{array}$ & 1.4 & 5.4 \\
\hline $\begin{array}{l}\text { Taur } \\
\text { ine }\end{array}$ & 0.97 & $\begin{array}{c}126 \\
.1\end{array}$ & 30 & 12 & $\begin{array}{c}126.1 \\
> \\
44.2 \\
126.1 \\
> \\
108.1\end{array}$ & $\begin{array}{c}0 . \\
18 \\
4\end{array}$ & $\begin{array}{c}0 . \\
00 \\
3\end{array}$ & $\begin{array}{c}0 . \\
99 \\
7\end{array}$ & $1000-50$ & $\begin{array}{l}1 \\
8 . \\
0\end{array}$ & 98.3 & 2.2 & 6.0 \\
\hline
\end{tabular}

${ }^{\dagger}\left(A_{x} / A_{i s}\right)=a\left(C_{x} / C_{i s}\right)+b$; where $A_{x}$ is the peak area of the analyte; $A_{i s}$ is the peak area of the internal standard; $\mathrm{C}_{\mathrm{x}}$ is the analyte concentration and $\mathrm{C}_{\mathrm{is}}$ is the internal standard concentration.

This article is protected by copyright. All rights reserved. 
Table 2. Nutritional and bioactive contents (mean \pm SE) in commercially available beef meat, according to the production system and muscle

\begin{tabular}{|c|c|c|c|c|c|c|}
\hline & & \multicolumn{2}{|c|}{ Production system $^{\dagger}$} & \multicolumn{2}{|c|}{ Muscle $^{\dagger}$} & \multirow[b]{2}{*}{$\begin{array}{c}\text { Interacti } \\
\text { on }^{\ddagger} \\
\text { PS } \times M \\
\end{array}$} \\
\hline & & Conventional & Organic & $\begin{array}{c}\text { Longissimus } \\
\text { thoracis }\end{array}$ & Supraspinatus & \\
\hline Water & $\begin{array}{l}\mathrm{g} \\
\mathrm{k} \\
\mathrm{g}^{-} \\
1\end{array}$ & $707.5 \pm 6.5$ & $734.3 \pm 5.5 * * *$ & $691.1 \pm 4.7$ & $741.7 \pm \stackrel{4.4}{* *}^{* *}$ & $*$ \\
\hline Collagen & $\begin{array}{l}\mathrm{g} \\
\mathrm{k} \\
\mathrm{g}^{-}\end{array}$ & $12.0 \pm 0.6$ & $14.5 \pm 1.0 *$ & $11.6 \pm 0.6$ & $14.0 \pm 0.8^{*}$ & \\
\hline Protein & $\begin{array}{l}\mathrm{g} \\
\mathrm{k} \\
\mathrm{g}^{-}\end{array}$ & $217.5 \pm 1.8$ & $215.0 \pm 3.9$ & $226.0 \pm 1.3^{* * *}$ & $207.3 \pm 1.5$ & \\
\hline Fat & $\begin{array}{l}\mathrm{g} \\
\mathrm{k} \\
\mathrm{g}^{-}\end{array}$ & $46.9 \pm{ }_{*}^{3.5 * *}$ & $31.8 \pm 1.5$ & $53.1 \pm 3.4^{* * * *}$ & $30.6 \pm 1.8$ & $* * *$ \\
\hline $\begin{array}{l}\text { Myristic } \\
\text { acid (C14:0) }\end{array}$ & $\begin{array}{l}\mathrm{m} \\
\mathrm{g} \\
\mathrm{g}^{-}\end{array}$ & $0.67 \pm 0.05$ & $0.59 \pm 0.05$ & $0.79 \pm 0.04 * * *$ & $0.49 \pm 0.04$ & $* *$ \\
\hline $\begin{array}{l}\text { Palmitic acid } \\
(\mathrm{C} 16: 0)\end{array}$ & $\begin{array}{l}\mathrm{m} \\
\mathrm{g} \\
\mathrm{g}^{-}\end{array}$ & $6.70 \pm 0.32 *$ & $5.57 \pm 0.45$ & $7.10 \pm 0.36 * *$ & $5.54 \pm 0.33$ & \\
\hline $\begin{array}{l}\text { Margaric } \\
\text { acid (C17:0) }\end{array}$ & $\begin{array}{l}\mathrm{m} \\
\mathrm{g} \\
\mathrm{g}^{-}\end{array}$ & $0.32 \pm 0.02$ & $0.27 \pm 0.02$ & $0.34 \pm 0.02$ & $0.28 \pm 0.02$ & $*$ \\
\hline $\begin{array}{l}\text { Stearic acid } \\
(\mathrm{C} 18: 0)\end{array}$ & $\begin{array}{l}\mathrm{m} \\
\mathrm{g} \\
\mathrm{g}^{-}\end{array}$ & $3.94 \pm 0.16$ & $4.23 \pm 0.37$ & $4.40 \pm 0.20 *$ & $3.66 \pm 0.23$ & \\
\hline $\begin{array}{l}\text { Total } \\
\text { saturated } \\
\text { fatty acids }\end{array}$ & $\begin{array}{l}\mathrm{m} \\
\mathrm{g} \\
\mathrm{g}^{-}\end{array}$ & $11.63 \pm 0.54$ & $10.66 \pm 0.89$ & $12.63 \pm 0.58 *$ & $9.98 \pm 0.60$ & \\
\hline $\begin{array}{l}\text { Palmitoleic } \\
\text { acid (C16:1, } \\
9 c)\end{array}$ & $\begin{array}{l}\mathrm{m} \\
\mathrm{g} \\
\mathrm{g}^{-}\end{array}$ & $0.95 \pm \underset{* *}{0.04}$ & $0.67 \pm 0.07$ & $0.88 \pm 0.06$ & $0.83 \pm 0.05$ & $* *$ \\
\hline $\begin{array}{l}\text { Elaidic acid } \\
(\mathrm{C} 18: 1,9 t)\end{array}$ & $\begin{array}{l}\mathrm{m} \\
\mathrm{g} \\
\mathrm{g}^{-}\end{array}$ & $1.48 \pm \underset{* *}{0.20 *}$ & $0.62 \pm 0.15$ & $1.91 \pm 0.20 * * *$ & $0.48 \pm 0.07$ & $* * *$ \\
\hline $\begin{array}{l}\text { Oleic acid } \\
(\mathrm{C} 18: 1,9 c)\end{array}$ & $\begin{array}{l}\mathrm{m} \\
\mathrm{g} \\
\mathrm{g}^{-}\end{array}$ & $11.33 \pm 0.46^{*}$ & $9.19 \pm 0.87$ & $10.89 \pm 0.56$ & $10.35 \pm 0.70$ & \\
\hline $\begin{array}{l}\text { Vaccenic } \\
\text { acid (C18:1, } \\
11 t)\end{array}$ & $\begin{array}{c}\mathrm{m} \\
\mathrm{g} \\
\mathrm{g}^{-}\end{array}$ & $0.64 \pm{ }_{*}^{0.03 *}$ & $0.45 \pm 0.05$ & $0.58 \pm 0.04$ & $0.57 \pm 0.04$ & $*$ \\
\hline
\end{tabular}

This article is protected by copyright. All rights reserved. 


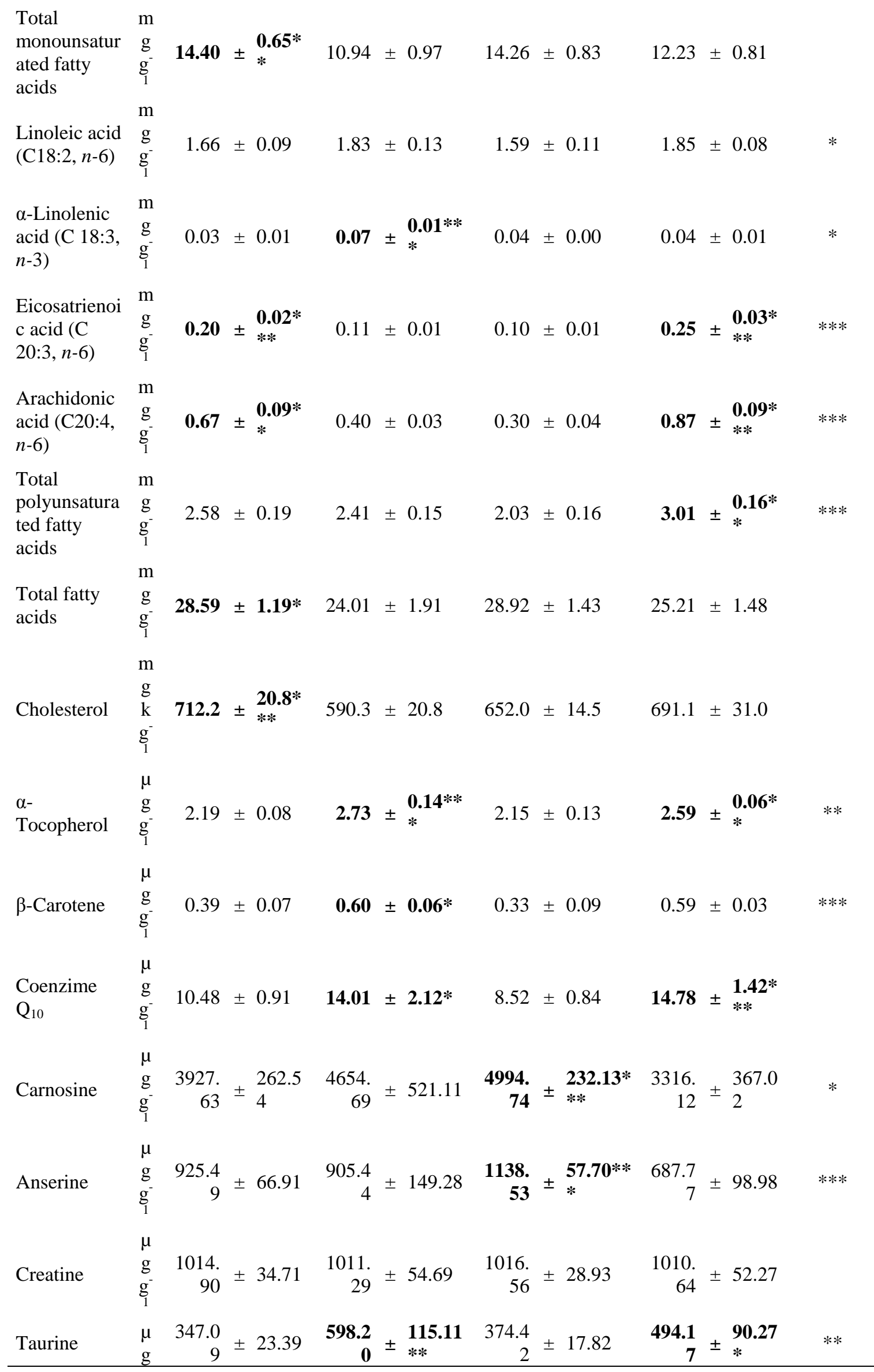

This article is protected by copyright. All rights reserved. 
${ }^{\dagger}$ Bold numbers and asterisks indicate significant differences within production systems or muscles.

${ }^{\ddagger}$ Asterisks indicate significant interaction between production system (PS) and muscle (M).

$* P<0.05 ; * * P<0.01 ; * * * P<0.001$

This article is protected by copyright. All rights reserved. 